\title{
Rapid detection of Streptococcus uberis in raw milk by loop-mediated isothermal amplification
}

\author{
J. B. W. J. Cornelissen, ${ }^{* 1}$ A. De Greeff, ${ }^{*}$ A. E. Heuvelink, † M. Swarts, † H. E. Smith, ${ }^{*}$ F. J. Van der Wal, ${ }^{*}$ \\ and 1Health4Food-Dutch Mastitis Diagnostics Consortium ${ }^{2}$ \\ ${ }^{*}$ Central Veterinary Institute, Department of Infection Biology, Wageningen UR, PO Box 65, 8200 AB Lelystad, the Netherlands \\ †GD-Animal Health, Arnsbergstraat 7, 7418 EZ Deventer, the Netherlands
}

\begin{abstract}
A loop-mediated isothermal amplification (LAMP) method to detect Streptococcus uberis in raw milk was developed and evaluated. Three genes $(\operatorname{sod} A, \operatorname{pau} A$, cpn60) were assessed for their suitability as targets in LAMP. The analytical sensitivity was 120, 120, and 12 fg per assay for the $\operatorname{sodA}$, pauA, and cpn60 assays, respectively, with a detectable signal within $8 \mathrm{~min}$ for the highest concentration (12 ng/assay) and $\sim 60 \mathrm{~min}$ for the lowest concentrations. The LAMP assays correctly identified 7 Strep. uberis strains among a set of 83 mastitis pathogens. To enable DNA isolation from raw milk, a new method was used in which a pretreatment with a cocktail of lysing enzymes was performed before an established procedure. This method resulted in an analytical sensitivity of $48 \mathrm{cfu} /$ assay for the $\operatorname{sod} A$ LAMP assay using raw milk spiked with Strep. uberis, corresponding to $2.4 \times 10^{4} \mathrm{cfu} / \mathrm{mL}$ milk. For raw milk samples from cows experimentally infected with Strep. uberis, results of enumeration were largely reflected by results of LAMP. Evaluation of the sodA LAMP assay with 100 raw milk field samples, of which 50 were Strep. uberis culture-negative and 50 Strep. uberis culture-positive, showed that the assay had a diagnostic sensitivity of $96.0 \%$ and a diagnostic specificity of $96.0 \%$. In conclusion, the described LAMP assay may offer a simple alternative for convenient and sensitive detection of $S$. uberis in raw milk, provided a compatible rapid DNA isolation procedure is available.
\end{abstract}

Key words: loop-mediated isothermal amplification (LAMP), Streptococcus uberis, mastitis, raw milk

\footnotetext{
Received November 25, 2015.

Accepted February 23, 2016.

${ }^{1}$ Corresponding author: jan.cornelissen@wur.nl

${ }^{2}$ This project also included Karien Griffioen (Faculty of Veterinary Medicine, Utrecht University, the Netherlands); Remco Dijkman, Manon M. C. Holstege, Theo J. G. M. Lam, Annet G. J. Velthuis, Geralda E. Hop, and Christian G. M. Scherpenzeel (GD Animal Health, the Netherlands); and Dik Mevius and René P. Achterberg (Central Veterinary Institute, Wageningen UR, the Netherlands).
}

\section{INTRODUCTION}

Mastitis is a common and costly infectious disease affecting dairy farms (Hogeveen et al., 2011) and one of the major reasons for use of antibiotics in dairy farming (Pieterse and Todorov, 2010). Several bacteria are implicated as causative agents, including Staphylococcus aureus, Streptococcus agalactiae, Streptococcus dysgalactiae, Streptococcus uberis, and coliforms such as Escherichia coli (Reyher et al., 2012). Monitoring of udder health is most frequently done by SCC and bacteriological culturing of milk (Lam et al., 2009). After culturing, additional typing techniques are required to determine the causative agent. Early detection and identification of pathogens could accelerate decisions on treatment, thereby contributing to animal health and reduced use of antibiotics (Trevisi et al., 2014).

To improve pathogen detection, various molecular diagnostic tests have been developed for identification of mastitis pathogens directly in milk (Koskinen et al., 2009), but rapid and sensitive tests with the potential for on-farm usage are not yet commercially available. Loop-mediated isothermal amplification (LAMP) is an alternative method of nucleic acid amplification to PCR that holds great promise for rapid on-farm diagnostics. The LAMP method is faster than PCR and less demanding in terms of the quality of the template DNA; moreover, an expensive dedicated machine is not required (Kaneko et al., 2007; Lucchi et al., 2010; Njiru et al., 2012).

For LAMP, at least 4 primers and a DNA polymerase with strand displacement activity are required (Notomi et al., 2000). Additional loop primers can accelerate the reaction but are not essential (Nagamine et al., 2002). Various methods of detection are possible, including the formation of optic visible magnesium pyrophosphate (turbidity) or fluorescence by DNA-intercalating dyes such as EvaGreen (Goto et al., 2007; Tomlinson et al., 2010; Bekele et al., 2011).

Although LAMP assays have been described for mastitis pathogens such as Staph. aureus and Strep. agalactiae (Zhao et al., 2013a), so far, LAMP has not 
been used for Streptococcus uberis, an important environmental pathogen accounting for a significant proportion of subclinical and clinical IMI (Bradley et al., 2007; Zadoks et al., 2011). To investigate the possibilities of LAMP for rapid on-farm diagnostics of mastitis pathogens, we developed a combined DNA isolation method and a LAMP assay for detection of Strep. uberis in raw milk. Assay performance was evaluated with raw milk obtained from experimentally infected animals, as well as with a selection of raw milk samples from the field, of which half were bacteriologically positive for Strep. uberis. The combination of the DNA isolation method and a LAMP assay targeting the Strep. uberis sodA gene allowed for rapid detection of Strep. uberis in raw milk, with outcomes that compared well with results of bacteriological methods.

\section{MATERIALS AND METHODS}

\section{Bacterial Strains and Growth Conditions}

Strains of various bacterial species isolated from milk of cows with mastitis (Table 1) were selected from in-house strain collections. Bacteria were grown on sheep blood agar heart infusion (HIS) plates (Central Veterinary Institute, Lelystad, the Netherlands) for $18 \mathrm{~h}$ at $37^{\circ} \mathrm{C}$ under aerobic conditions. The species of each isolate was confirmed by matrix-assisted laser desorption/ionization time-of-flight mass spectrometry (MALDI-TOF MS; MALDI Biotyper 3.1, Bruker Daltonics GmbH, Leipzig, Germany).

For DNA isolation, bacteria were harvested by scraping from the surface of a plate grown to confluence. The bacteria were suspended in $1 \mathrm{~mL}$ of PBS $(0.1 \mathrm{M} \mathrm{NaCl}$, $33 \mathrm{~m} M \mathrm{Na}_{2} \mathrm{HPO}_{4}, 17 \mathrm{~m} M \mathrm{KH}_{2} \mathrm{PO}_{4} \cdot 2 \mathrm{H}_{2} \mathrm{O}$; pH 7.4) and pelleted by centrifugation at $10,000 \times g$ for $15 \mathrm{~min}$. The pellets were stored at $-20^{\circ} \mathrm{C}$ until further use.

From the selected set of bacteria, one Strep. uberis strain (strain 2.28) was chosen as a positive control. This isolate was cultured on sheep blood agar HIS plates for $18 \mathrm{~h}$ at $37^{\circ} \mathrm{C}$. From one colony, an overnight culture (18 h) was prepared in Todd-Hewitt broth (Oxoid Ltd., Basingstoke, UK) at $37^{\circ} \mathrm{C}$ under aerobic conditions. A 1:100 dilution in Todd-Hewitt broth was grown to exponential phase (optical density of 0.5 at $600 \mathrm{~nm}$ ). The number of colony-forming units per milliliter of the liquid culture was determined by serial dilution and plating on HIS agar. Subsequently, bacteria were pelleted by centrifugation at $10,000 \times g$ for $10 \mathrm{~min}$, and the pellet was resuspended in Nutrient Broth Medium No. 2 (Central Veterinary Institute) with $15 \%$ glycerol to a concentration of $1.9 \times 10^{9} \mathrm{cfu} / \mathrm{mL}$. Aliquots of 1 $\mathrm{mL}$ were frozen at $-80^{\circ} \mathrm{C}$ until further use.
For the experimental infection of cows, Strep. uberis strain O140J (Leigh et al., 1990) was used. This strain was grown on Columbia agar blood base plates (Oxoid Ltd.) containing $6 \%$ (vol/vol) horse blood and $0.1 \%$ (vol/vol) esculin for $18 \mathrm{~h}$ at $37^{\circ} \mathrm{C}$. Liquid cultures of Strep. uberis O140J were grown in Todd-Hewitt broth (Oxoid Ltd.) for $16 \mathrm{~h}$ at $37^{\circ} \mathrm{C}$. Subsequently, cultures were diluted 1:10 in Todd-Hewitt broth and grown to exponential phase to prepare the inoculum.

\section{Isolation of DNA from Bacterial Cultures and Raw Milk}

Aliquots of $200 \mu \mathrm{L}$ of suspended bacteria containing $0.4 \times 10^{9} \mathrm{cfu}$ (see above) or $200 \mu \mathrm{L}$ of milk were incubated for $30 \mathrm{~min}$ at $37^{\circ} \mathrm{C}$ with $50 \mu \mathrm{L}$ of Tris-EDTA buffer $[20 \mathrm{mmol} / \mathrm{L}$ Tris-HCl (pH 8.0), $2 \mathrm{mmol} / \mathrm{L} \mathrm{EDTA}]$ containing achromopeptidase, lysostaphin, lysozyme, and mutanolysin $(1,000 \mathrm{U} / \mathrm{mL}, 20 \mu \mathrm{g} / \mathrm{mL}, 1 \mathrm{mg} / \mathrm{mL}$, and $100 \mathrm{U} / \mathrm{mL}$, respectively; Sigma-Aldrich Chemie, Zwijndrecht, the Netherlands). Subsequently, the mix was incubated for $1 \mathrm{~h}$ at $56^{\circ} \mathrm{C}$ with $20 \mu \mathrm{L}$ of proteinase $\mathrm{K}$ in $180 \mu \mathrm{L}$ of ATL buffer from the DNeasy Blood and Tissue Kit (Qiagen, Venlo, the Netherlands), and bacterial DNA was isolated according to the procedure of the manufacturer and taken up in $200 \mu \mathrm{L}$ of water. Concentrations of DNA were determined by using a NanoDrop spectrophotometer (Thermo Fisher Scientific, Pittsburgh, PA).

Table 1. Bacterial strains $(n=83)$, originating from cows with mastitis, that were used as reference material (all strains were from an in-house strain collection)

\begin{tabular}{llc}
\hline Gram status & Species & $\begin{array}{c}\text { No. of } \\
\text { strains }\end{array}$ \\
\hline Gram-positive & Staphylococcus aureus & 3 \\
& Staphylococcus chromogenes & 8 \\
Staphylococcus epidermidis & 5 \\
Staphylococcus haemolyticus & 2 \\
Staphylococcus hyicus & 4 \\
Staphylococcus simulans & 3 \\
& Staphylococcus warneri & 4 \\
& Streptococcus agalactiae & 7 \\
& Streptococcus castoreus & 2 \\
Streptococcus dysgalactiae & 13 \\
& Streptococcus uberis & 7 \\
& Corynebacterium bovis & 1 \\
& Enterococcus faecalis & 2 \\
& Listeria monocytogenes & 2 \\
& Trueperella pyogenes & 1 \\
& Serratia marcescens & 3 \\
Escherichia coli & 7 \\
Klebsiella oxytoca & 3 \\
Kram-negative & Salmonella speumoniae & 3 \\
& &
\end{tabular}




\section{Experimental Strep. uberis Infection of Cows}

Ten Holstein-Friesian cows in first lactation were inoculated with Strep. uberis. Before inoculation via the teat canal, teats were disinfected with alcohol. Two cross-quarters of each animal were infected with $500 \mathrm{cfu}$ of Strep. uberis by inserting a teat cannula into the teat canal, followed by a gentle upward-directed massage of the mammary gland. The remaining 2 quarters were mock challenged with PBS and served as within-cow control quarters. After inoculation, milk samples were taken twice daily. Fresh raw milk was analyzed bacteriologically and SCC were determined as described below. Aliquots of milk were stored at $-20^{\circ} \mathrm{C}$ until further analysis by LAMP.

To determine the SCC, milk was fixed in $2 \%$ formaldehyde containing $2 \mu \mathrm{g} / \mathrm{mL}$ eosin solution for $50 \mathrm{~min}$ at $55^{\circ} \mathrm{C}$. After fixation, the milk was cooled to room temperature. Fixed cells were diluted 100-fold in Tolle electrolyte solution ( $2 \%$ Triton-X100, $12.5 \%$ ethanol, $1 \%$ of $37 \%$ formalin, $84.5 \%$ of $0.9 \% \mathrm{NaCl}$ ) and incubated for 15 min at $80^{\circ} \mathrm{C}$. After incubation, samples were cooled to room temperature. Subsequently, milk SCC were determined for each quarter using a Coulter Counter (Beckman Coulter, Fullerton, CA). Milk samples were serially diluted with sterile saline solution, plated onto Columbia agar blood base plates (Central Veterinary Institute), and enumerated after $18 \mathrm{~h}$ of incubation at $37^{\circ} \mathrm{C}$.

All animal experiments were approved under number 870.474.05.00.01 by the ethical committee of the Central Veterinary Institute of Wageningen UR, Lelystad, the Netherlands, in accordance with the Dutch law on animal experiments.

\section{Raw Milk Field Samples}

A collection of 100 raw milk samples was compiled by selecting 50 Strep. uberis-positive milk samples obtained from 35 different herds and 50 Strep. uberisnegative milk samples obtained from 32 different herds. These samples had been collected from cows in the Netherlands between October and November 2014.

Milk samples $(10 \mu \mathrm{L})$ were streaked onto $6 \%$ sheep blood agar plates (GD-Animal Health, Deventer, the Netherlands) and incubated at $37^{\circ} \mathrm{C}$. Presumptive growth of mastitis-causing pathogens on the plates was examined after 18 to $24 \mathrm{~h}$ and again after $48 \mathrm{~h}$. If no growth was observed, samples were re-examined by culturing $(10 \mu \mathrm{L})$ on $6 \%$ sheep blood agar after freezing $\left(-20^{\circ} \mathrm{C}\right)$ and subsequent overnight incubation at $37^{\circ} \mathrm{C}$. Identification of presumptive mastitis-causing pathogens was performed by MALDI-TOF MS. The number of Strep. uberis colonies after direct culture was recorded semiquantitatively in 3 categories: $1-5,6-10$, and $>10 \mathrm{cfu} /$ plate. Aliquots of milk were kept at $-20^{\circ} \mathrm{C}$ until further analysis by LAMP.

\section{LAMP Assay Design}

Three genes that have been used in the literature as targets for PCR to detect Strep. uberis were selected (Alber et al., 2004; Gillespie and Oliver, 2005). The sequences of the Strep. uberis genes coding for superoxide dismutase $\mathrm{A}(\operatorname{sod} A)$, plasminogen activator $\mathrm{A}(\operatorname{pau} A)$, and chaperonin Cpn60 (cpn60) were retrieved from the National Center for Biotechnology Information (NCBI) database (http://www.ncbi.nlm.nih.gov), using one sequence for each gene to search for related sequences [accession numbers GU392740.1, GU392692.1, and GU392383.1, respectively; for each gene, only one copy number of these genes was found present in genome of Strep. uberis (accession number AM946015.1)]. Conserved regions were identified by sequence alignments using NBCI Blast search (http://blast.ncbi.nlm.nih. gov) for $\operatorname{sod} A(\mathrm{n}=23), \operatorname{pau} A(\mathrm{n}=61)$, and $\operatorname{cpn} 60(\mathrm{n}=$ 39). The conserved regions were used for primer design with Primer Explorer V4 (http://primerexplorer.jp/ elamp4.0.0/index.html). As the LAMP primer design software consistently generated assays with only one loop primer, all LAMP assays were equipped with 5 primers (Table 2).

\section{LAMP Reactions}

The LAMP assays were performed using a commercially available mix that includes a polymerase with strand displacement activity and EvaGreen (Isothermal Master Mix; OptiGene, Horsham, UK). The LAMP reactions were carried out on a scale of 26.0 $\mu \mathrm{L}$, containing the forward inner primer (FIP) and the backward inner primer BIP $(2.0 \mu \mathrm{mol} / \mathrm{L}$ each $), \mathrm{F} 3$ and B3 primers $(0.2 \mu \mathrm{mol} / \mathrm{L}$ each $)$, and, depending on the design, $1.0 \mu \mathrm{mol} / \mathrm{L}$ of the backward loop or forward loop primer, $2.0 \mu \mathrm{L}$ of template DNA, and $6 \mu \mathrm{L}$ of ROX Passive reference (Eurogentec, Liege, Belgium). The LAMP assays were performed in 96-well plates and always included negative controls $(2.0 \mu \mathrm{L}$ of water) and positive controls $(2.0 \mu \mathrm{L}$ of Strep. uberis DNA of $58 \mathrm{ng} /$ $\mu \mathrm{L})$. Reactions were incubated at temperatures ranging from 60 to $63^{\circ} \mathrm{C}$, in an ABI 7500 Real-Time PCR system (Applied Biosystems, Foster City, CA) for 67.5 min, during which fluorescence by EvaGreen was measured (90 "cycles" of $45 \mathrm{~s}$ ). The threshold was manually set at 50\% in the linear phase of the amplification plot, similar to the selection of a cutoff-value for real-time PCR (Caraguel et al., 2011). The time point at which fluorescent signals pass this threshold is referred to as 
Table 2. Sequences of loop-mediated isothermal amplification (LAMP) primers, which were designed as described (Notomi et al., 2000) ${ }^{1}$

\begin{tabular}{lll}
\hline Gene & Primer & $5^{\prime}$-3' Oligonucleotide sequence \\
\hline sodA & Su sodA F3 & TGGCGTTATTATCTGATGTGT (F3) \\
& Su sodA B3 & AGAYCCAAAACGTCCCGT (B3c) \\
& Su sodA FIP & ATGGTTAAGATGTCCGCCTCCCATCAATTCCAGAAGATATTCGT (F1c-F2) \\
& Su sodA BIP & TTCACCTGAGAAAACAGAATCACTTCTTTAAATGCATCAAAAGAACC (B1-B2c) \\
& Su sodA Bloop & CGGAAGTAGCTTCTGCTATTGAT (BLP) \\
& Su sodA FIP & DIG-ATGGTTAAGATGTCCGCCTCCCATCAATTCCAGAAGATATTCGT (F1c-F2) \\
& Su sodA BIP & Biotin-TTCACCTGAGAAAACAGAAATCACTTCTTTAAATGCATCAAAAGAACC (B1-B2c) \\
pauA & Su pauA F3 & TTAATGCTTTGGGATATTTGG (F3) \\
& Su pauA B3 & CAATCTTTTGGTTTGATCTGTT (B3c) \\
& Su pauA FIP & TCGGGATCAATATATCTAGCGTAGTGCTACTCAACCATCAAAGGT (F1c-F2) \\
& Su pauA BIP & TGCCATAAATGTTGATGGTTTTGTCCATGATGAATTCCTCTAATAAGGAT (B1-B2c) \\
& Su pauA Bloop & GGAATCATAACCGGTTATTGCTGC (BLP) \\
& Su cpn60 F3 & TTCAGGAAAAGAGGCGAT (F3) \\
& Su cpn60 B3 & ACCATATATTGTGATAAGTATCCG (B3c) \\
& Su cpn60 FIP & ACACGTTCCATAGCTTCTGAGATATAAGTAGCTGCCGTGTCAT (F1c-F2) \\
& Su cpn60 BIP & AGGCAATGATGGTGTTATCACAATCGGTCAAATTGCATCCCTT (B1-B2c) \\
& Su cpn60 Floop & CACGTGGTATGGAAACAGAACT (FLP)
\end{tabular}

${ }^{1} \mathrm{Su}=$ Streptococcus uberis; F1c = sequence complementary to F1; F2c = sequence complementary to F2; B3c = sequence complementary to B3; $\mathrm{BLP}=$ backward loop primer; FLP = forward loop primer. The forward inner primer (FIP) contains the F1 complementary sequence and the F2 direct sequence; the backward inner primer (BIP) contains the B1 direct sequence and the B2 complementary sequence.

time-to-positivity $(\mathbf{T p})$ and is expressed in minutes. To confirm the identity of amplification products, melting curve analyses were performed after amplification by decreasing the temperature from $95^{\circ} \mathrm{C}$ to $60^{\circ} \mathrm{C}$ while measuring fluorescence.

\section{Evaluation of LAMP Assays}

The analytical sensitivity of each LAMP assay was calculated using Strep. uberis DNA isolated from $200 \mu \mathrm{L}$ of culture (Strep. uberis strain $2.28 ; 1.9 \times 10^{9} \mathrm{cfu} / \mathrm{mL}$ ) and dissolved in $200 \mu \mathrm{L}$ of elution buffer at a final DNA concentration of $58.40 \mathrm{ng} / \mu \mathrm{L}$. This DNA preparation was tested in a 10 -fold serial dilution ( $2 \mu \mathrm{L}$ per assay), resulting in a range from $12 \mathrm{ng}$ (corresponding to 3.8 $\times 10^{5} \mathrm{cfu} /$ assay) to $1.2 \mathrm{fg}$ of Strep. uberis DNA (corresponding to $0.04 \mathrm{cfu} /$ assay) per assay. The dilutions were tested with all 3 LAMP assays at 4 temperatures $\left(60,61,62\right.$, and $\left.63^{\circ} \mathrm{C}\right)$.

To assess the diagnostic specificity of the designed Strep. uberis LAMP assays, 83 mastitis isolates, including 7 Strep. uberis isolates, were used (Table 1). Of each isolate, $1 \mathrm{ng} / \mu \mathrm{L}$ template DNA was tested with the sodA, pauA, and cpn60 LAMP assays at 62, 60, and $62^{\circ} \mathrm{C}$, respectively. Results were used to determine $\mathrm{Tp}$ cut-off values: as $\mathrm{Tp}$ values indicate the time required to generate a fluorescent signal, Tp cut-off values indicate below which $\mathrm{Tp}$ value a result can be deemed positive. The Tp cut-off values were defined as the average Tp value of the 76 non-Strep. uberis isolates minus 3 times the standard deviation, using only experiments in which a signal was detected within the length of the experiment. Results were only considered positive when
Tp values remained below the calculated cut-offs and, as such, were used to calculate diagnostic specificity.

To determine the analytical sensitivity of the $\operatorname{sod} A$ LAMP in milk, the assay was tested on DNA isolated from raw milk spiked with a culture of Strep. uberis strain $2.28\left(1.9 \times 10^{9} \mathrm{cfu} / \mathrm{mL}\right)$. Raw milk that was culture negative for Strep. uberis was used to make a 5 -fold serial dilution, starting with a 1:5 dilution of the $1.9 \times 10^{9} \mathrm{cfu} / \mathrm{mL}$ Strep. uberis culture (i.e., $3.8 \times$ $10^{8} \mathrm{cfu} / \mathrm{mL}$ ). This resulted in a series of Strep. uberisspiked milk samples from which DNA was isolated and of which $2 \mu \mathrm{L}$ was used for amplification by LAMP, resulting in a series corresponding to a range from $7.6 \times$ $10^{5} \mathrm{cfu} /$ assay to $10 \mathrm{cfu} /$ assay. Performance of the Strep. uberis LAMP assays in milk was evaluated using 48 raw milk samples from experimentally infected cows. These 4 series of 12 longitudinal milk samples were tested with the $\operatorname{sod} A$ and pauA LAMP assays; results were compared with bacteriological results. Performance of the $\operatorname{sodA}$ LAMP assay was further evaluated by testing a set of 100 raw milk field samples (see above), of which 50 samples were culture positive for $S$. uberis.

\section{Pilot with End-Point Readout by Lateral Flow Assay}

To investigate the possibilities of a LAMP endpoint readout using a lateral flow assay, a LAMP amplification on Strep. uberis sodA was performed with the $5^{\prime}$ Digoxigenin-labeled FIP primer and the $5^{\prime}$ biotinlabeled BIP primer. To this end, a 5 -fold serial dilution of Strep. uberis bacteria was made in raw milk and used for DNA isolation. By applying $2 \mu \mathrm{L}$ for amplification by LAMP, a range was tested from $7.6 \times 10^{5} \mathrm{cfu} /$ 
assay to $10 \mathrm{cfu} /$ assay. Upon amplification by LAMP, the labeled product was analyzed using a lateral flow device (LFD), the PCRD Nucleic Acid Detector assay (Abingdon Health, York, UK). Five microliters of product was mixed with $75 \mu \mathrm{L}$ of PCRD extraction buffer, applied to the LFD and left for $10 \mathrm{~min}$ to allow the reaction. This test contains antibodies against DIG and FAM on, respectively, lines 1 and 2, and a third line, marked C (for control) with biotin that catches the visible label (i.e., avidin-labeled gold nanoparticles); this line is used as a check for actual flow of added sample material within the assay. Detection of the LAMP amplicon was indicated by the presence of a black line on the reaction pad at position 1 .

\section{Statistical Analyses}

The performance of Strep. uberis LAMP assays was analyzed for statistical significance by the Mann-Whitney U-test in the GraphPad Prism version 5.0 software (GraphPadSoftware Inc., La Jolla, CA), with $P<0.05$ considered significant. Calculation of diagnostic sensitivity, specificity, and Cohen's kappa coefficient was performed as described (Mackinnon, 2000).

\section{RESULTS}

\section{Analytic Sensitivity of Strep. uberis LAMP Assays Using Serial Dilutions of DNA}

The performance of the Strep. uberis LAMP assays for 3 target genes was tested at 4 different temperatures. Ten-fold serial dilutions were prepared, resulting in a range from $12 \mathrm{ng}$ to $1.2 \mathrm{fg}$ of Strep. uberis DNA per assay. The $\mathrm{Tp}$ values ranged from 10 to $58 \mathrm{~min}$ for the sodA LAMP, from 8 to $63 \mathrm{~min}$ for the pauA LAMP, and from 8 to 60 min for the cpn60 LAMP assay (Figure 1). The lowest amount of Strep. uberis DNA that could be detected was $120 \mathrm{fg} /$ assay in the $\operatorname{sodA}$ and pauA assays and $12 \mathrm{fg} /$ assay in the cpn60 assay, corresponding to a calculated $3.8 \mathrm{cfu} /$ assay $(1,900 \mathrm{cfu} / \mathrm{mL}$ of sample) for the $\operatorname{sod} A$ and $p a u A$ assays and a calculated $0.4 \mathrm{cfu} /$ assay $(190 \mathrm{cfu} / \mathrm{mL}$ of sample) for the cpn60 assay. These results showed that the analytical sensitivity of LAMP for amplification of Strep. uberis DNA was high for all 3 LAMP designs tested.

\section{Performance of Strep. uberis LAMP Assays Within a Set of Reference Strains}

For each assay, one reaction temperature was selected for further investigations based on the $\mathrm{Tp}$ values at the lowest DNA concentrations detectable (Figure 1).
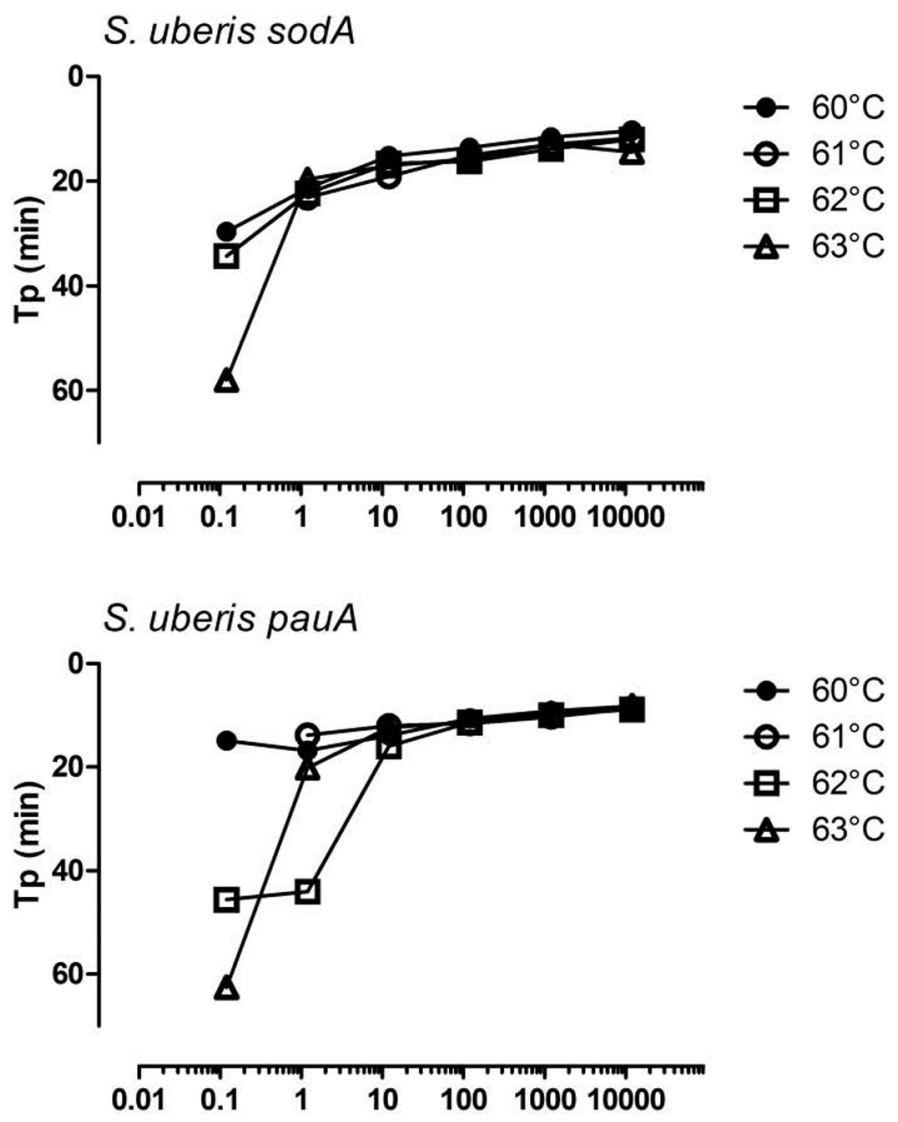

\section{S. uberis cpn60}

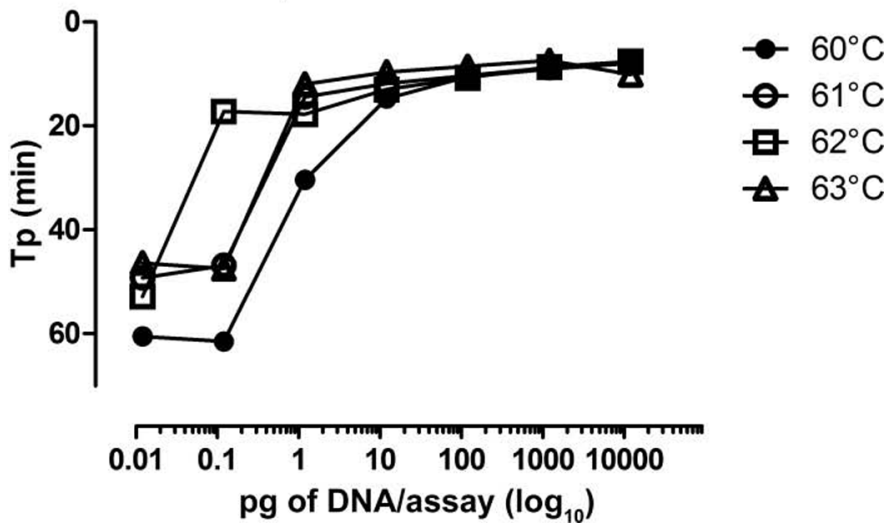

Figure 1. Analytical sensitivity of Streptococcus uberis loop-mediated isothermal amplification (LAMP) assays. Three targets for Strep. uberis were tested $(\operatorname{sod} A, \operatorname{pauA}$, and $\operatorname{cpn} 60)$ in a LAMP assay at temperatures ranging from 60 to $63^{\circ} \mathrm{C}$, with a 10 -fold serial dilution of $S$. uberis DNA, ranging from $12 \mathrm{ng}$ to $1.2 \mathrm{fg} /$ assay. Results are presented as time-to-positivity $(\mathrm{Tp})$ in minutes.

A temperature of $62^{\circ} \mathrm{C}$ was selected that was suitable for at least 2 of the 3 assays ( $\operatorname{sod} A$ and $\operatorname{cpn} 60)$; for the LAMP assay on pauA, the optimal temperature of $60^{\circ} \mathrm{C}$ was selected for further experiments. 
At the selected temperatures, performance of the LAMP assays for all 3 target genes was evaluated using equal quantities of DNA from a set of 83 mastitisrelated bacterial isolates, including 7 Strep. uberis isolates (Table 1). The LAMP assays targeting $\operatorname{sod} A$, pauA, and cpn60 were all able to detect Strep. uberis (n $=7$ ) within $10 \mathrm{~min}$, with median $\mathrm{Tp}$ of 8,5 , and $4 \mathrm{~min}$, respectively (Figure 2). All other bacterial isolates (n $=76$ ) resulted in higher Tp values in all LAMP assays ( $\geq 33 \mathrm{~min})$ or did not yield a $\mathrm{Tp}$ value at all within the length of the experiment (Figure 2). The difference between Strep. uberis strains $(\mathrm{n}=7)$ and non-Strep. uberis strains $(\mathrm{n}=76)$ was statistically significant $(P$ $<0.0001 ; 2$-tailed Mann-Whitney test with $95 \%$ confidence) for all 3 LAMP assays.

With the aid of an additional melting curve analysis for each LAMP assay, a check was performed on the identity of the amplification products generated. Each LAMP assay on the 7 Strep. uberis strains resulted in products with characteristic melting temperatures $(\mathbf{T m})$, with averages of $83.8^{\circ} \mathrm{C} \pm 0.2^{\circ} \mathrm{C}, 82.3^{\circ} \mathrm{C} \pm 0.2^{\circ} \mathrm{C}$, and $84.1^{\circ} \mathrm{C} \pm 0.2^{\circ} \mathrm{C}( \pm \mathrm{SEM})$ for, respectively, the $\operatorname{sod} A$, pauA, and cpn60 LAMP assays (not shown). For nonStrep. uberis isolates that resulted in a Tp within the length of the experiment, observed Tm values varied between $70^{\circ} \mathrm{C}$ and $86^{\circ} \mathrm{C}$. For the cpn60 LAMP, various products of non-Strep. uberis strains were found, with a Tm within the same temperature range as specific Strep. uberis amplicons $\left(84.1^{\circ} \mathrm{C} \pm 0.2^{\circ} \mathrm{C}\right.$; not shown). These results suggest that the $\operatorname{sod} A$ and pauA LAMP assays are more specific for Strep. uberis, whereas the cpn60 LAMP is less specific for Strep. uberis.

To evaluate the performance of the LAMP assays for correct speciation within the mastitis strain set, sensitivity and specificity of the tests were determined. To this end, Tp cut-off values were calculated based on the Tp values found for non-Strep. uberis strains, as described in Materials and Methods. Calculated cutoffs were, respectively, 53, 39, and $28 \mathrm{~min}$ for the $\operatorname{sod} A$, pauA, and cpn60 LAMP assays (Figure 2). Using these cut-offs, all individual results were scored (positive or negative) for Strep. uberis. The derived diagnostic sensitivities and specificities of the $\operatorname{sod} A, \operatorname{pau} A$, and cpn60 LAMP assays were 100\% (not shown; see Figure 2), which suggests that, within the mastitis strain set, all LAMP designs performed well when used for speciation. However, the distance between the median $\mathrm{Tp}$ values for positive samples $(8,5$, and $4 \mathrm{~min}$. for $\operatorname{sodA}$, pauA, and cpn60 LAMP) and the calculated Tp cut-off values $(53,39$, and $28 \mathrm{~min}$, respectively) was very small for the cpn60 LAMP assay compared with the other 2 assays (see Figure 2). This indicates that a higher background level of amplification occurred in the cpn60 LAMP than in the sodA and pauA LAMP
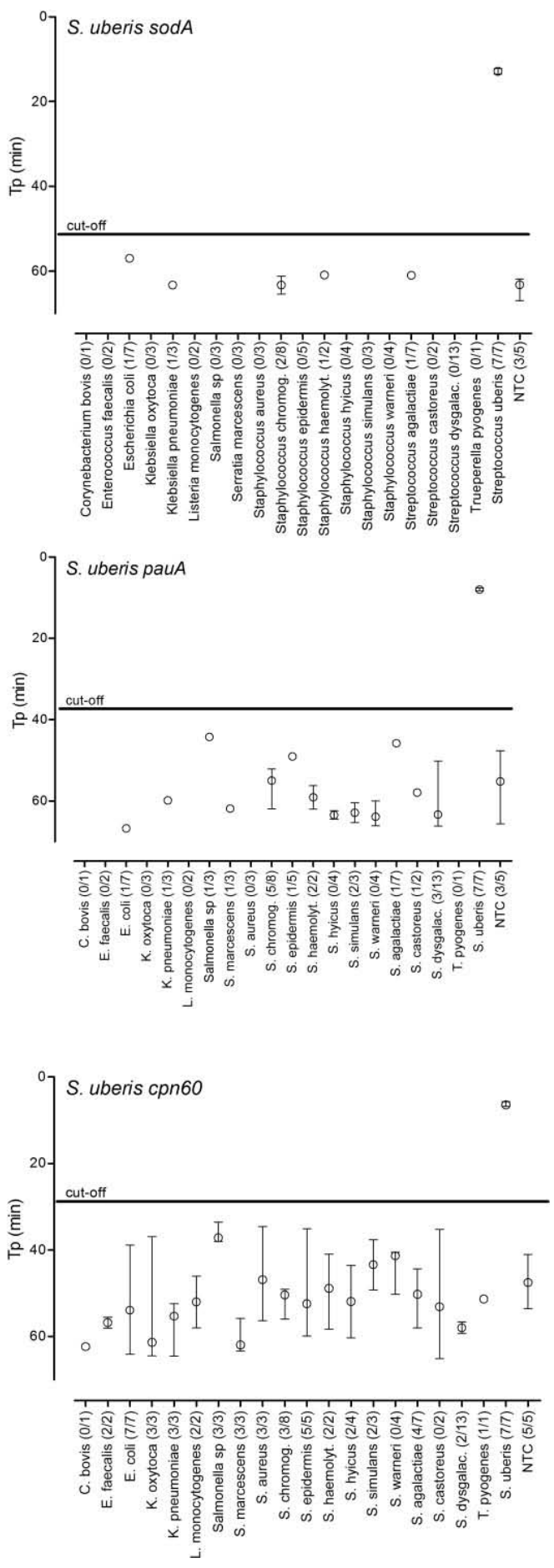

Figure 2. Diagnostic specificity of 3 Streptococcus uberis loop-mediated isothermal amplification (LAMP) assays. For a panel of 83 bacterial isolates, 3 Strep. uberis LAMP assays were performed (for sodA, pauA, and cpn60), using a standard concentration of $1 \mathrm{ng}$ of DNA/ $\mu \mathrm{L}$. Results are presented as time-to-positivity ( $\mathrm{Tp}$ ) in minutes; for each of the 3 LAMP assays, per bacterial species, the median Tp with its range is given. Between parentheses (x-axis) is indicated per species how many out of the tested isolates were positive, where positivity is defined as the appearance of a signal within the length of the experiment. The Tp cut-off values were calculated as described in Materials and Methods. 
assays. Because of this observation, together with the detection of nonspecific amplicons of non-Strep. uberis strains (melting curve analysis) in the cpn60 LAMP assay, only the sodA and pauA assays were considered for further analysis.

\section{Evaluation of Strep. uberis LAMP Assays Using Raw Milk from Experimentally Infected Cows}

Only the $\operatorname{sod} A$ and pauA LAMP assays (see above) were evaluated using raw milk from experimentally infected cows. These 4 series of 12 longitudinal milk samples (48) were from 4 different cows that showed mastitis symptoms, had a high $\mathrm{SCC}\left(>10^{6}\right.$ cells $\left./ \mathrm{mL}\right)$ from $\mathrm{d} 2$ until the end of the experiment, and had a high load of Strep. uberis $\left(>10^{6} \mathrm{cfu} / \mathrm{mL}\right)$ at the end of the experiment.

Before experimental infection, milk of all quarters was bacteriologically negative for Strep. uberis (d -5 and -4; Figure 3). After Strep. uberis inoculation at d 0 , Strep. uberis numbers sharply increased, and after a dip (d 2), numbers increased to $10^{6}$ to $10^{7} \mathrm{cfu} / \mathrm{mL}$ at $\mathrm{d} 5$. The SCC were elevated from d 2, peaked at d 8 , and declined thereafter. The amount of Strep. uberis detected by the 2 LAMP assays in general reflected the observed bacterial counts (Figure 3), except that the dip in the count at $\mathrm{d} 2$, as observed by bacteriology, was not observed until d 3 with the LAMP assays.

These results demonstrated that both the $\operatorname{sod} A$ and pauA LAMP assays are capable of detecting Strep. uberis in raw milk samples.

\section{Analytic Sensitivity of the sodA LAMP Assay in Raw Milk Spiked with Strep. uberis}

The sodA and pauA LAMP assays gave comparable results with the raw milk samples from infection experiments, but only the sodA LAMP was selected for further evaluation because, within the reference set, its capability for differentiation between Strep. uberis and non-Strep. uberis isolates was better than of the pauA (and cpn60) LAMP assay (see Figure 2). The analytic sensitivity of the Strep. uberis sodA LAMP assay only (see above) was tested on DNA isolated from raw milk spiked with Strep. uberis. The lowest number of Strep. uberis that could be detected was $48 \mathrm{cfu} /$ assay, corresponding to $2.4 \times 10^{4} \mathrm{cfu}$ per $\mathrm{mL}$ milk (Figure $4 \mathrm{~A}$ ).

\section{Pilot with Endpoint Readout by Lateral Flow Assay}

The DNA extracts from a 5 -fold serial dilution of Strep. uberis in milk, tested in the sodA LAMP assay
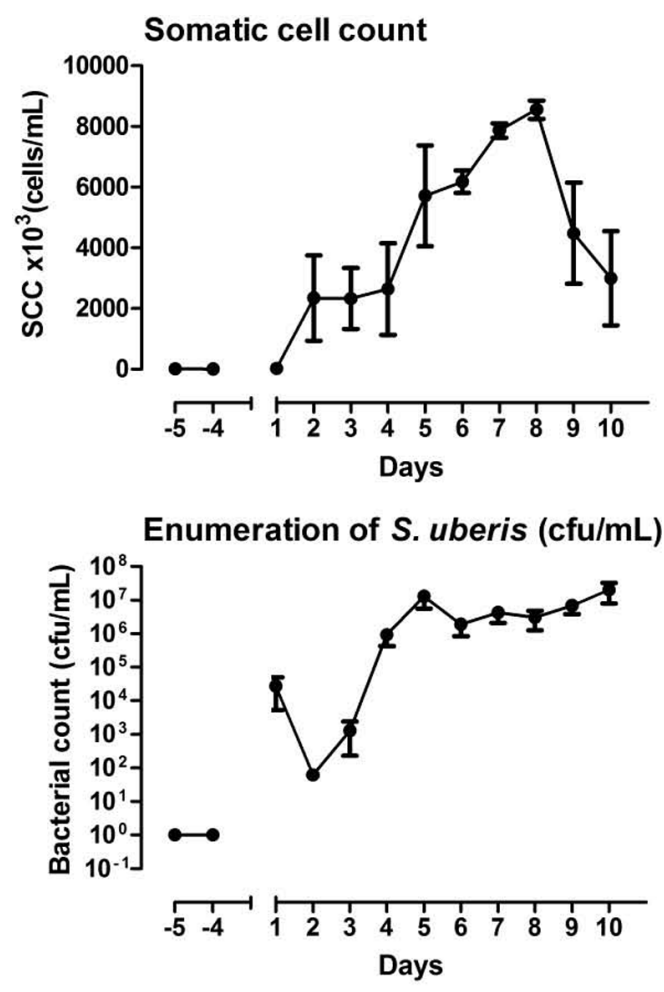

S. uberis SOdA LAMP
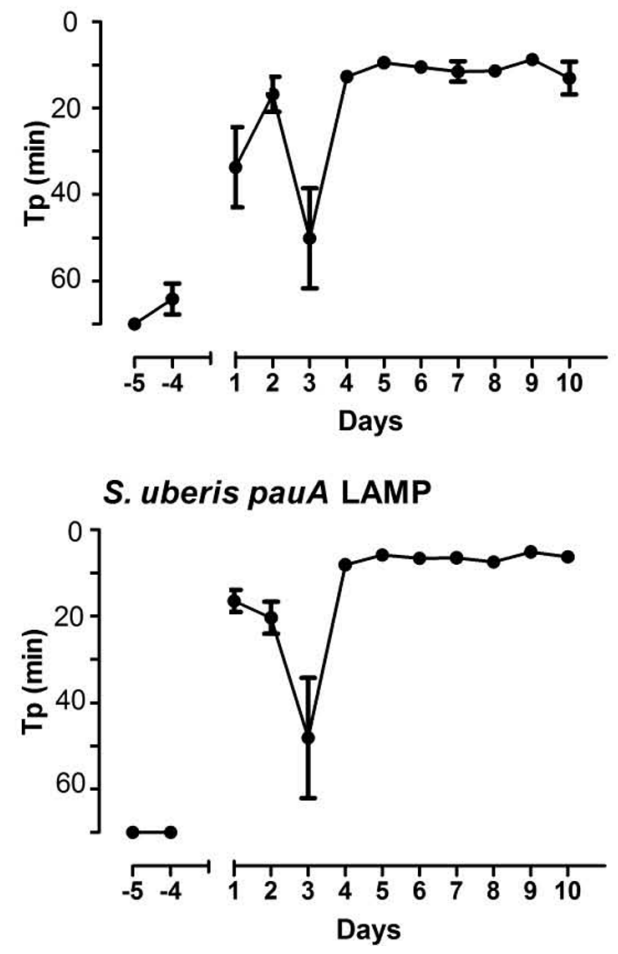

Figure 3. Detection of Streptococcus uberis by loop-mediated isothermal amplification (LAMP) assay in raw milk of experimentally infected cows. For 4 series of 12 raw milk samples from cows experimentally infected with Strep. uberis (d 0), means are given with standard error bars for SCC, count of S. uberis, and the results of the LAMP assays targeting Strep. uberis sodA and pauA. Results of the LAMP assays are presented as time-to-positivity $(\mathrm{Tp})$ in minutes. 
(Figure 4A), were also tested using the DIG and biotinlabeled primers to enable detection of the amplification product by an LFD assay. The LAMP-LFD combination was able to detect Strep. uberis to $240 \mathrm{cfu} /$ assay, corresponding to $1.2 \times 10^{5} \mathrm{cfu} / \mathrm{mL}$ of milk (Figure $4 \mathrm{~B}$ ).
Evaluation of Strep. uberis sodA LAMP Assay Using Raw Milk Field Samples

Next, the $\operatorname{sod} A$ LAMP assay was evaluated using 50 Strep. uberis-positive and 50 Strep. uberis-negative raw

A
$\begin{array}{lll}1 & 2 & 3\end{array}$
45
$\begin{array}{ll}6 & 7\end{array}$

\section{S. uberis sodA}

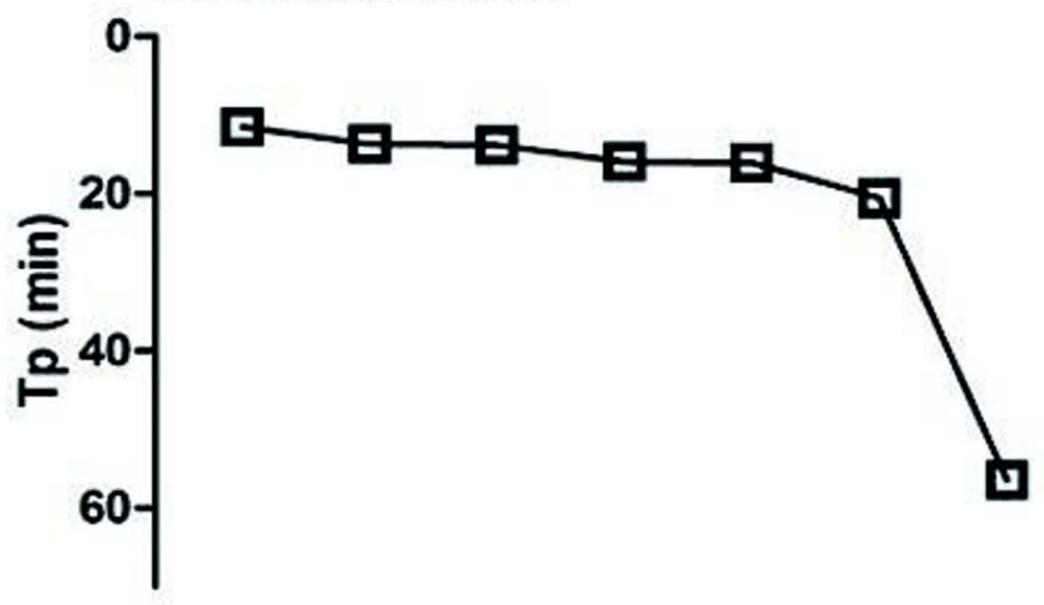

B
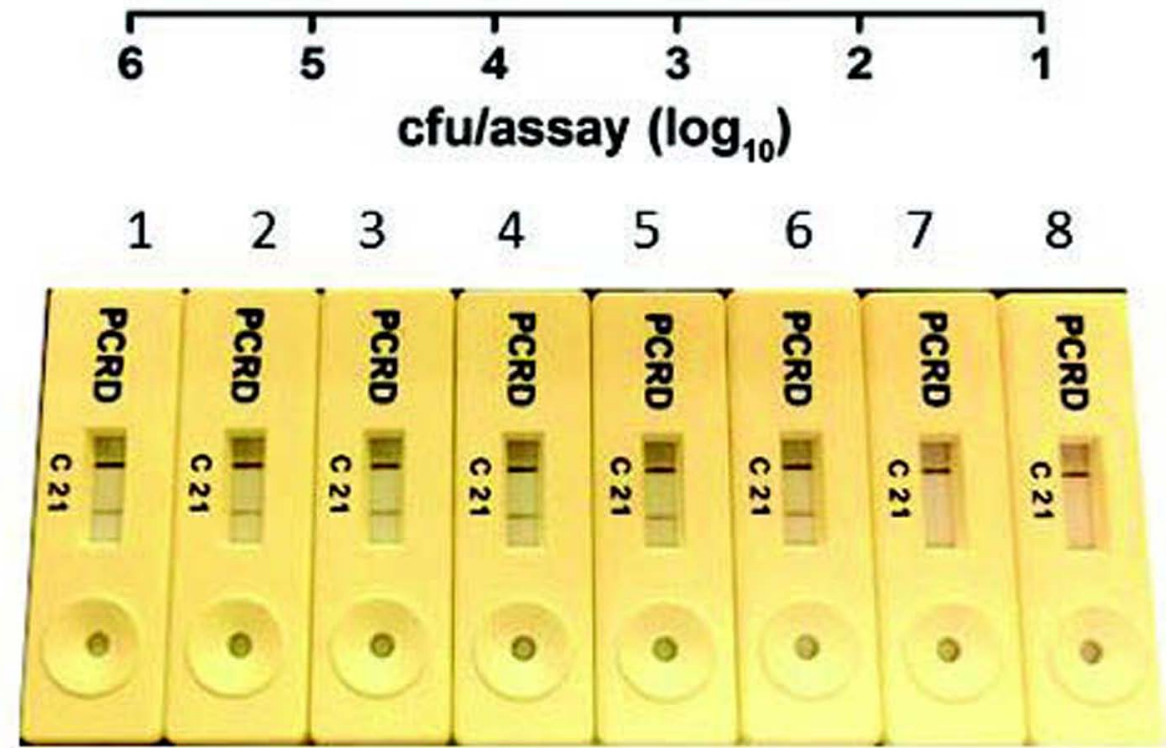

Figure 4. Analytical sensitivity of Streptococcus uberis sodA loop-mediated isothermal amplification (LAMP) assay in spiked milk. A 5-fold serial dilution of Strep. uberis bacteria, made in raw milk samples and corresponding to a range from $7.6 \times 10^{5}$ to 10 cfu/assay, was subjected to DNA isolation. The resulting samples were tested in the Strep. uberis sodA LAMP assay (A). The first 7 samples $\left(7.6 \times 10^{5}\right.$ to 240 cfu/assay; sample numbers 1 to 7 ) and a negative control sample (water; sample 8) were also tested in a lateral flow assay (B). Products labeled with digoxigenin (DIG) can be immobilized by anti-DIG at position 1 and become visible as a line, whereas a line at position $\mathrm{C}$ becomes visible to indicate that sample material has correctly flown through the assay. Line 2 detects FAM/Biotin- or FITC/Biotin-labeled amplicons. Color version available online. 
milk field samples as determined by culture. Out of the 50 bacteriological Strep. uberis-positive samples, 48 were positive for Strep. uberis by the LAMP assay within the length of the experiment. Melting curve analysis showed that the amplification products had a $\mathrm{Tm}$ of $83.8^{\circ} \mathrm{C} \pm 1.0^{\circ} \mathrm{C}$, which corresponded to the $\mathrm{Tm}$ of the product of the positive control $\left(83.8^{\circ} \mathrm{C}\right)$. Out of the 50 bacteriological Strep. uberis-negative samples, 48 were Strep. uberis-negative by LAMP. Two bacteriologically negative Strep. uberis samples were found positive by LAMP (false positives; Tp $39.3 \mathrm{~min}$ and 6.7 min with, respectively, $\mathrm{Tm}$ of 84.0 and $83.3^{\circ} \mathrm{C}$ ), and 2 bacteriologically positive Strep. uberis samples were missed by LAMP (false negatives). The calculated sensitivity and specificity of the sodA S. uberis LAMP assay compared with culture/MALDI-TOF MS were, respectively, $96.0 \%$ (95\% CI: 88.29-99.51) and 96.0\% (95\% CI: 88.29-99.51), with a Cohen's kappa coefficient of 0.92 (95\% CI: 84.32-99.68), indicating almost perfect agreement (Mackinnon, 2000) of the LAMP assay with culture and MS.

\section{DISCUSSION}

For the detection and identification of pathogens in milk from cows with mastitis, simple and rapid diagnostics are required to accelerate decisions on treatment (Pieterse and Todorov, 2010; Gurjar et al., 2012), thereby contributing to animal health and a reduced use of antibiotics. As molecular diagnostics can be more rapid than classical methods, nucleic acid amplification by thermal cycling (PCR) is widely used for pathogen detection but is not common for detection on farm or at a modest veterinary laboratory. Suitable targets for identification of Strep. uberis by real-time PCR have been described (Phuektes et al., 2003; Gillespie and Oliver, 2005; McDonald et al., 2005; Chiang et al., 2008; Shome et al., 2012), and commercial real-time PCR kits (e.g., PathoProof Mastitis PCR Assay, Finnzymes Oy/ThermoFisher Scientific, Waltham, MA) are on the market. However, the use of relatively expensive equipment (thermal cycler) remains essential. Isothermal amplification of nucleic acid sequences by LAMP has potential as a method for on-farm diagnostics, as LAMP is faster and cheaper than PCR, and less demanding in terms of the quality of the template DNA (Zhang et al., 2014). The LAMP method has been used for the detection of many foodborne bacteria, viruses, and parasites by using on-site equipment (often for real-time LAMP) and lateral flow immunoassays for endpoint detection (Zhang et al., 2014).

Applications of LAMP for the detection of mastitiscausing pathogens (Tie et al., 2012; Suebsing et al.,
2013) and relevant resistance genes (i.e., for methicillinresistant Staph. aureus and extended-spectrum betalactamase; Anjum et al., 2013; Su et al., 2014) have been reported. The LAMP assay can be performed using real-time thermal cyclers but expensive equipment is not required; cheaper options, more suitable for point-of-care applications, are also available (Fischbach et al., 2015).

The aim of this study was to explore the possibilities of LAMP for pathogen detection in milk, for which Strep. uberis was chosen as target organism. Streptococcus uberis is a major mastitis pathogen for which no LAMP assay has yet been described. For this study, 3 LAMP assays were designed on target genes that have been used for PCR detection of Strep. uberis (Alber et al., 2004; Gillespie and Oliver, 2005).

The analytical sensitivity of the 3 LAMP assays was high, with detection to $120 \mathrm{fg} /$ assay for the Strep. uberis $\operatorname{sod} A$ and pauA LAMP assays, and detection to $12 \mathrm{fg} /$ assay (the lowest concentration tested) for the cpn60 LAMP assay. The assay is usually performed at a temperature between 60 and $65^{\circ} \mathrm{C}$. In this study, all LAMP assays were tested at 60 to $63^{\circ} \mathrm{C}$. Higher temperatures were not tested because the analytical sensitivity did not improve with increasing temperatures, whereas the Tp reached values close to, or over, an hour in time.

Within a set of mastitis reference strains, all assays had a diagnostic sensitivity and specificity of $100 \%$. Importantly, the results of all LAMP assays with isolates of other Streptococcus species (Strep. agalactiae, Strep. castoreus, Strep. dysgalactiae) resulted in Tp values that were higher than the calculated cut-offs (Figure 2 ); that is, negative for Strep. uberis, indicating that the designed assays are sufficiently specific within the genus Streptococcus. Extensive evaluation of related Lactococcus species and of species from the related family of Enterococcaceae was not performed. However, for instance, the Strep. uberis sodA region used for LAMP design is highly specific for Strep. uberis within the genus Streptococcus and indeed within the order Lactobacillales, as shown by BLAST analyses.

In contrast to the sodA and pauA LAMP assays, we observed that the cpn60 LAMP assay resulted in signals for all non-Strep. uberis isolates throughout the length of the experiment. As these signals reached above the set cut-off, the outcomes were deemed negative for Strep. uberis, but it showed that the cpn60 LAMP assay had a high background compared with the other 2 LAMP assays. This was reflected by the low Tp cut-off value for the cpn60 LAMP assay, which is based on the Tp values observed for non-Strep. uberis strains. In addition, some of these amplified products showed Tm values in the same range as specific Strep. uberis- 
derived product. Despite the high analytical sensitivity, the cpn60 LAMP assay was therefore not considered for further evaluation.

The $\operatorname{sod} A$ LAMP was selected for further evaluation for 2 reasons. First, although the $\operatorname{sod} A$ and pauA LAMP assays gave comparable results with the raw milk samples from infection experiments, within the reference set, the capability for differentiation between Strep. uberis and non-Strep. uberis isolates was better for sodA LAMP than for pauA LAMP. Second, pauA may not be present in all bovine Strep. uberis isolates (Gilchrist et al., 2013).

An aspect that was not investigated in this study was the application of LAMP for multiple pathogens in one assay. Analysis of the performance of Strep. uberis LAMP assays was performed with a set of reference strains, all originating from cows with mastitis, and ideally at least a subset of these pathogens would be targeted simultaneously with similar assays. For now, it is anticipated that the most practical approach to multiplexing is to execute multiple assays in parallel.

An important aspect of this study was to find a protocol for isolation of microbial DNA from milk that could be used on farm and that would result in DNA that could be used as template in LAMP. Initial attempts with a simple and quick procedure (Sowmya et al., 2012) to isolate DNA from gram-positive bacteria (Strep. uberis, Staph. aureus) from raw milk resulted in an unsatisfactory analytical sensitivity (not shown). Therefore, we shifted the focus toward efficiency of DNA isolation, at the cost of speed and simplicity. To isolate Strep. uberis DNA from bacteria in milk, the samples were first incubated with a cocktail of lysing enzymes, followed by DNA isolation with a commercially available product. This procedure works well but takes $2.5 \mathrm{~h}$; for a true point-of-care application of LAMP for mastitis, the need remains for a LAMP-compatible rapid and simple method to isolate DNA from raw milk. We observed that, in terms of count (cfu)/assay, the sodA LAMP assay was 10 times more sensitive using diluted DNA than DNA isolated from raw milk, which suggests that more-efficient DNA isolation protocols would allow for increased sensitivity of LAMP. In addition, the high sensitivity of a commercially available real-time PCR, that includes a procedure for DNA isolation from milk (Koskinen et al., 2009), indicates that for both the current and a future on-site procedures, optimizations will be required to increase the DNA yield and adaptation to the protocol to increase the DNA input in the test.

Although LAMP is not a quantitative diagnostic tool, and does not exactly reproduce PCR or enumeration, when raw milk samples from an experimental infection trial with Strep. uberis were tested, results of the $\operatorname{sod} A$ and pauA LAMP assays largely reflected the presence of bacteria: intermediate at the start of the experiment, followed by a dip and a subsequent high plateau. This demonstrates that the method used for DNA isolation combined with LAMP can be used to detect Strep. uberis in milk. The occurrence of a dip in bacterial count at d 2 was noteworthy, and it might reflect an immune response to the challenge with Strep. uberis. The dip in the bacterial count at d 2 was not detectable until d 3 in the LAMP assay. Culture and enumeration detect only live bacteria, whereas LAMP also detects DNA of dead bacteria. This difference may explain the delayed peak in detection by LAMP of DNA from bacteria that were used for infection at $\mathrm{d} 1$. A solution to circumvent discrepancies between culture and nucleic acid amplification may be provided by the application of propidium monoazide (PMA) to inhibit amplification of DNA from dead bacteria, as has been used for PCR in dairy products (Zhang et al., 2015). Because PMA can be used in milk (Weber et al., 2014) and is compatible with LAMP (Zhao et al., 2013b), this is a possibility, but it remains to be seen whether it is practical for point-of-care testing or indeed required when testing milk for mastitis pathogens.

When testing the Strep. uberis sodA LAMP assay with raw milk field samples, high specificity (96\%) and sensitivity $(96 \%)$ were found, using results from bacteriology (culture and confirmation by MALDITOF MS) as reference. This shows the feasibility of the combination of the DNA isolation method and LAMP as a method for detecting Strep. uberis in raw milk. As Strep. uberis (and other mastitis-causing pathogens) is also an environmental agent, the presence of target pathogens in milk may depend in part on the hygiene of the procedure for obtaining milk; this needs to be established. As these assays were performed in the absence of a cut-off that could help to determine if results are to be interpreted as positive or negative, a melting curve analysis for each LAMP assay was performed after amplification, to confirm whether observed $\mathrm{Tp}$ values were accompanied by amplification products with the correct Tm. This may be too time consuming for point-of-care testing but is, at this stage, an absolute requirement to evaluate results in the absence of a validated cut-off for raw milk.

Due to the high analytical sensitivity of the LAMP assay, small amounts of Strep. uberis were detected in milk, as illustrated by the observation that during reexamination by bacteriology (not shown), one sample, initially negative by bacteriology but positive by LAMP, appeared positive for Strep. uberis, whereas one sample, initially positive by bacteriology but negative by LAMP, appeared negative for Strep. uberis (not shown). Although together this resulted in slightly improved performance in sensitivity (98.0\%) and specificity (98.0\%), 
these observations suggest that, for both LAMP and bacteriology in some samples, measurements were done close to the limit of detection. This indicates the need for a practical cut-off, which could be established with a large set of known positive and negative samples. A discrepancy between culture and DNA amplification is not unknown: culture-negative milk samples and realtime PCR-positive samples represent a large proportion of samples in conventional bacteriology (Taponen et al., 2009). In this particular case, for the few culturepositive milk samples that were negative by LAMP, many explanations are conceivable, such as sequence heterogeneity, inhibitory components in raw milk, or reduced assay sensitivity by suboptimal DNA isolation. Nevertheless, the results with field samples show that LAMP is very sensitive in detecting Strep. uberis down to a few colony-forming units per assay and closely matches the results of culture.

To test the potential of LAMP as an on-farm test, we performed a pilot experiment using an LFD assay to make an endpoint reading of a LAMP assay. The preliminary results suggest that LAMP combined with lateral flow is a viable option for rapid on-farm diagnostics, but this type of assay would need to be optimized; the LFD assay was less sensitive than the assay with real-time readout. Furthermore, instead of open LFD, commercially available closed systems can be used to prevent contamination. Taken together, all components for rapid on-farm detection of pathogens in milk by isothermal amplification are available.

\section{CONCLUSIONS}

This study presents a combination of a DNA isolation method and a LAMP assay for detection of Strep. uberis in raw milk that compares well with bacteriological methods. The procedure offers a simple and rapid alternative for convenient and sensitive detection of Strep. uberis in raw milk. Challenges that remain before LAMP is suitable for point-of-care detection of mastitis pathogens are the availability of a compatible rapid isolation procedure of DNA from bacteria in raw milk and a convenient method for performing multiple LAMP assays simultaneously on one sample.

\section{ACKNOWLEDGMENTS}

The authors thank Henk Wisselink, Kees Veldman, and Dik Mevius (Central Veterinary Institute, Wageningen UR, the Netherlands) for bacterial isolates, and Cor Schoen and Willem Stol (Plant Research International, Wageningen UR, the Netherlands) for helpful discussions concerning LAMP. This research was partly funded (A. E. H., M. S.) by ZuivelNL (DairyNL; Den Haag, the Netherlands) and the Ministry of Economic Affairs (Den Haag, the Netherlands) in the 1Health4 Food public-private partnership (TKI-AF 12067) in the project "Diagnostiekontwikkeling en -toepassing voor het optimaliseren van uiergezondheid," executed by the Dutch Mastitis Diagnostics Consortium.

\section{REFERENCES}

Alber, J., A. El-Sayed, C. Lammler, A. A. Hassan, and M. Zschock. 2004. Polymerase chain reaction mediated identification of Streptococcus uberis and Streptococcus parauberis using species-specific sequences of the genes encoding superoxide dismutase A and chaperonin 60. J. Vet. Med. B Infect. Dis. Vet. Public Health 51:180-184.

Anjum, M. F., F. Lemma, D. J. Cork, D. Meunier, N. Murphy, S. E. North, N. Woodford, J. Haines, and L. P. Randall. 2013. Isolation and detection of extended spectrum beta-lactamase (ESBL)-producing Enterobacteriaceae from meat using chromogenic agars and isothermal loop-mediated amplification (LAMP) assays. J. Food Sci. 78:M1892-M1898.

Bekele, B., J. Hodgetts, J. Tomlinson, N. Boonham, and P. Nikolic. 2011. Use of a real-time LAMP isothermal assay for detecting $16 \mathrm{SrII}$ and 16SrXII phytoplasmas in fruit and weeds of the Ethiopian Rift Valley. Plant Pathol. 60:345-355.

Bradley, A. J., K. A. Leach, J. E. Breen, L. E. Green, and M. J. Green. 2007. Survey of the incidence and aetiology of mastitis on dairy farms in England and Wales. Vet. Rec. 160:253-257.

Caraguel, C. G., H. Stryhn, N. Gagne, I. R. Dohoo, and K. L. Hammell. 2011. Selection of a cutoff value for real-time polymerase chain reaction results to fit a diagnostic purpose: Analytical and epidemiologic approaches. J. Vet. Diagn. Invest. 23:2-15.

Chiang, Y. C., W. Y. Pai, C. Y. Chen, and H. Y. Tsen. 2008. Use of primers based on the heat shock protein genes $h s p 70, h s p 40$, and $h s p 10$, for the detection of bovine mastitis pathogens Streptococcus agalactiae, Streptococcus uberis and Streptococcus bovis. Mol. Cell. Probes 22:262-266.

Fischbach, J., N. C. Xander, M. Frohme, and J. F. Glokler. 2015. Shining a light on LAMP assays - A comparison of LAMP visualization methods including the novel use of berberine. Biotechniques 58:189-194.

Gilchrist, T. L., D. G. Smith, J. L. Fitzpatrick, R. N. Zadoks, and M. C. Fontaine. 2013. Comparative molecular analysis of ovine and bovine Streptococcus uberis isolates. J. Dairy Sci. 96:962-970.

Gillespie, B. E., and S. P. Oliver. 2005. Simultaneous detection of mastitis pathogens, Staphylococcus aureus, Streptococcus uberis, and Streptococcus agalactiae by multiplex real-time polymerase chain reaction. J. Dairy Sci. 88:3510-3518.

Goto, M., H. Hayashidani, K. Takatori, and Y. Hara-Kudo. 2007. Rapid detection of enterotoxigenic Staphylococcus aureus harbouring genes for four classical enterotoxins, SEA, SEB, SEC and SED, by loop-mediated isothermal amplification assay. Lett. Appl. Microbiol. 45:100-107.

Gurjar, A., G. Gioia, Y. Schukken, F. Welcome, R. Zadoks, and P. Moroni. 2012. Molecular diagnostics applied to mastitis problems on dairy farms. Vet. Clin. North Am. Food Anim. Pract. 28:565-576.

Hogeveen, H., K. Huijps, and T. J. Lam. 2011. Economic aspects of mastitis: New developments. N. Z. Vet. J. 59:16-23.

Kaneko, H., T. Kawana, E. Fukushima, and T. Suzutani. 2007. Tolerance of loop-mediated isothermal amplification to a culture medium and biological substances. J. Biochem. Biophys. Methods 70:499-501.

Koskinen, M. T., J. Holopainen, S. Pyorala, P. Bredbacka, A. Pitkala, H. W. Barkema, R. Bexiga, J. Roberson, L. Solverod, R. Piccinini, D. Kelton, H. Lehmusto, S. Niskala, and L. Salmikivi. 2009. Analytical specificity and sensitivity of a real-time polymerase chain reaction assay for identification of bovine mastitis pathogens. J. Dairy Sci. 92:952-959. 
Lam, T., R. Olde Riekerink, O. Sampimon, and H. Smith. 2009. Mastitis diagnostics and performance monitoring: a practical approach. Ir. Vet. J. 62(Suppl. 4):S34-S39.

Leigh, J. A., T. R. Field, and M. R. Williams. 1990. Two strains of Streptococcus uberis, of differing ability to cause clinical mastitis, differ in their ability to resist some host defence factors. Res. Vet. Sci. 49:85-87.

Lucchi, N. W., A. Demas, J. Narayanan, D. Sumari, A. Kabanywanyi, S. P. Kachur, J. W. Barnwell, and V. Udhayakumar. 2010. Realtime fluorescence loop mediated isothermal amplification for the diagnosis of malaria. PLoS ONE 5:e13733.

Mackinnon, A. 2000. A spreadsheet for the calculation of comprehensive statistics for the assessment of diagnostic tests and inter-rater agreement. Comput. Biol. Med. 30:127-134.

McDonald, W. L., B. N. Fry, and M. A. Deighton. 2005. Identification of Streptococcus spp. causing bovine mastitis by PCR-RFLP of 16S-23S ribosomal DNA. Vet. Microbiol. 111:241-246.

Nagamine, K., T. Hase, and T. Notomi. 2002. Accelerated reaction by loop-mediated isothermal amplification using loop primers. Mol. Cell. Probes 16:223-229.

Njiru, Z. K., D. Yeboah-Manu, T. P. Stinear, and J. A. Fyfe. 2012. Rapid and sensitive detection of Mycobacterium ulcerans by use of a loop-mediated isothermal amplification test. J. Clin. Microbiol. 50:1737-1741.

Notomi, T., H. Okayama, H. Masubuchi, T. Yonekawa, K. Watanabe, N. Amino, and T. Hase. 2000. Loop-mediated isothermal amplification of DNA. Nucleic Acids Res. 28:E63.

Phuektes, P., G. F. Browning, G. Anderson, and P. D. Mansell. 2003. Multiplex polymerase chain reaction as a mastitis screening test for Staphylococcus aureus, Streptococcus agalactiae, Streptococcus dysgalactiae and Streptococcus uberis in bulk milk samples. J. Dairy Res. 70:149-155.

Pieterse, R., and S. D. Todorov. 2010. Bacteriocins-Exploring alternatives to antibiotics in mastitis treatment. Braz. J. Microbiol. 41:542-562.

Reyher, K. K., D. Haine, I. R. Dohoo, and C. W. Revie. 2012. Examining the effect of intramammary infections with minor mastitis pathogens on the acquisition of new intramammary infections with major mastitis pathogens - A systematic review and meta-analysis. J. Dairy Sci. 95:6483-6502.

Shome, B. R., M. Bhuvana, S. D. Mitra, N. Krithiga, R. Shome, D. Velu, A. Banerjee, S. B. Barbuddhe, K. Prabhudas, and H. Rahman. 2012. Molecular characterization of Streptococcus agalactiae and Streptococcus uberis isolates from bovine milk. Trop. Anim. Health Prod. 44:1981-1992.

Sowmya, N., M. S. Thakur, and H. K. Manonmani. 2012. Rapid and simple DNA extraction method for the detection of enterotoxigenic Staphylococcus aureus directly from food samples: comparison of PCR and LAMP methods. J. Appl. Microbiol. 113:106-113.
Su, J., X. Liu, H. Cui, Y. Li, D. Chen, Y. Li, and G. Yu. 2014. Rapid and simple detection of methicillin-resistance Staphylococcus aureus by orf $X$ loop-mediated isothermal amplification assay. BMC Biotechnol. 14:8.

Suebsing, R., J. Kampeera, B. Tookdee, B. Withyachumnarnkul, W. Turner, and W. Kiatpathomchai. 2013. Evaluation of colorimetric loop-mediated isothermal amplification assay for visual detection of Streptococcus agalactiae and Streptococcus iniae in tilapia. Lett. Appl. Microbiol. 57:317-324.

Taponen, S., L. Salmikivi, H. Simojoki, M. T. Koskinen, and S. Pyorala. 2009. Real-time polymerase chain reaction-based identification of bacteria in milk samples from bovine clinical mastitis with no growth in conventional culturing. J. Dairy Sci. 92:2610-2617.

Tie, Z., W. Chunguang, W. Xiaoyuan, Z. Xinghua, and Z. Xiuhui. 2012. Loop-mediated isothermal amplification for detection of Staphylococcus aureus in dairy cow suffering from mastitis. J. Biomed. Biotechnol. 2012:435982.

Tomlinson, J. A., M. J. Dickinson, and N. Boonham. 2010. Detection of Botrytis cinerea by loop-mediated isothermal amplification. Lett. Appl. Microbiol. 51:650-657.

Trevisi, E., A. Zecconi, S. Cogrossi, E. Razzuoli, P. Grossi, and M. Amadori. 2014. Strategies for reduced antibiotic usage in dairy cattle farms. Res. Vet. Sci. 96:229-233.

Weber, M., J. Geissert, M. Kruse, and A. Lipski. 2014. Comparative analysis of bacterial community composition in bulk tank raw milk by culture-dependent and culture-independent methods using the viability dye propidium monoazide. J. Dairy Sci. 97:6761-6776.

Zadoks, R. N., J. R. Middleton, S. McDougall, J. Katholm, and Y. H. Schukken. 2011. Molecular epidemiology of mastitis pathogens of dairy cattle and comparative relevance to humans. J. Mammary Gland Biol. Neoplasia 16:357-372.

Zhang, X., S. B. Lowe, and J. J. Gooding. 2014. Brief review of monitoring methods for loop-mediated isothermal amplification (LAMP). Biosens. Bioelectron. 61:491-499.

Zhang, Z., W. Liu, H. Xu, Z. P. Aguilar, N. P. Shah, and H. Wei. 2015. Propidium monoazide combined with real-time PCR for selective detection of viable Staphylococcus aureus in milk powder and meat products. J. Dairy Sci. 98:1625-1633.

Zhao, X., Y. Li, M. Park, J. Wang, Y. Zhang, X. He, F. Forghani, L. Wang, G. Yu, and D. H. Oh. 2013a. Loop-mediated isothermal amplification assay targeting the femA gene for rapid detection of Staphylococcus aureus from clinical and food samples. J. Microbiol. Biotechnol. 23:246-250.

Zhao, X., J. Wang, F. Forghani, J. H. Park, M. S. Park, K. H. Seo, and D. H. Oh. 2013b. Rapid detection of viable Escherichia coli $\mathrm{O} 157$ by coupling propidium monoazide with loop-mediated isothermal amplification. J. Microbiol. Biotechnol. 23:1708-1716. 